\title{
GAYA HIDUP DALAM MENGONSUMSI SAYUR DAN BUAH SERTA TINGKAT KECUKUPAN GIZI ANAK USIA SEKOLAH DASAR DI KOTA METRO
}

\author{
(The Lifestyle on Consumption of Vegetables and Fruits and Nutritional Adequacy Level of Elementary \\ School Students in Metro City)
}

Karina Ayesha, Yaktiworo Indriani, Begem Viantimala

Jurusan Agribisnis, Fakultas Pertanian, Universitas Lampung, Jl. Prof. Dr. Soemantri Brojonegoro No.1

Bandar Lampung 35145, e-mail: yaktiworo.indriani@fp.unila.ac.id

\begin{abstract}
This research aims to find out the lifestyle on the consumption of vegetables and fruits, nutritional adequacy level, and factors affecting the consumption of vegetables and fruits in Metro City. The research is conducted purposely in Elementary School 1 Metro and Elementary School 6 Metro; involving 52 samples of $5^{\text {th }}$ grade elementary school children obtained by using a simple random sampling method. Primary and secondary data were collected in November 2017 - May 2018. Vegetables and fruits consumption data were collected by 24-hour recall and analyzed descriptively by Variety of Nutritional Adequacy Value and statistically by multiple linear regression. The results showed that the nutritional adequacy level of elementary school students was as much as $82.69 \%$, but they were experiencing deficiency of calcium and vitamin $C$. Average value of the variety of nutritional adequacy was $85 \%$, which means that the food consumed by children is diverse. The lifestyle of elementary school students in consuming vegetables and fruits was indicated that they rarely bought various serving of vegetables and fruits since they like vegetables and fruits served at home. Elementary school students preferred local to import fruits and prefer buying them at traditional market to modern market. They agree that eating vegetables and fruits was important and had good impact on health. The factors which affect the consumption of vegetables and fruits were the number and types of vegetables and fruits consumed, the consumption frequency of vegetables and fruits, and the children's opinion.
\end{abstract}

Key words: fruits, lifestyle, nutritional adequacy level, vegetables

\section{PENDAHULUAN}

Pertanian merupakan salah satu sektor yang berperan penting dalam pemenuhan kebutuhan hidup di Indonesia. Sektor pertanian berperan sebagai penghasil bahan kebutuhan pokok seperti pangan, sandang, papan, dan menyediakan lapangan pekerjaan bagi sebagian besar penduduk di Indonesia. Pangan merupakan kebutuhan dasar dan sebagai sumber zat gizi bagi manusia yang dikonsumsi sehari-hari.

Pola konsumsi pangan adalah susunan beragam pangan dan hasil olahannya yang biasa dimakan oleh seseorang yang dicerminkan dalam jumlah, jenis, frekuensi, dan sumber bahan makanan (Harper, Deaton, dan Driskel 1986). Pola konsumsi pangan yang sehat dan terpenuhinya kebutuhan gizi merupakan strategi penting dalam usaha mencegah permasalahan gizi sejak dini.

Pangan yang dikonsumsi secara beragam dalam jumlah cukup dan seimbang akan mampu memenuhi kebutuhan zat gizi. Keanekaragaman pangan tersebut mencakup kelompok padi-padian, umbi-umbian, pangan hewani, minyak dan lemak, buah dan biji berminyak, kacang-kacangan, gula, sayur dan buah, dan lainnya. Sayur dan buah merupakan kelompok pangan yang memiliki banyak manfaat bagi tubuh. Mengonsumsi sayur dan buah merupakan salah satu syarat dalam memenuhi menu gizi seimbang. Konsumsi sayur dan buah berguna bagi anak-anak sebagai generasi penerus bangsa untuk mendapatkan zat-zat gizi yang cukup. Konsumsi sayur dan buah memiliki pengaruh positif dalam pertumbuhan dan perkembangan anak.

Masyarakat perkotaan yang tingkat mobilitasnya tinggi mengalami pergeseran pola makan dari tinggi karbohidrat, tinggi serat, dan rendah lemak ke rendah karbohidrat dan serat, tinggi lemak dan protein (Santoso 2011). Menurut Soewitomo (2007), perubahan gaya hidup dalam mengonsumsi buah menjadikan konsumen cenderung lebih menginginkan buah yang dapat langsung dikonsumsi. Kota Metro merupakan kota dengan tingkat konsumsi sayur dan buah masih di bawah 
standar PPH (DKP Kota Metro 2017). Pada tahun 2016, skor PPH dari kelompok pangan sayur dan buah di Kota Metro adalah sebesar 27,0 dimana skor pola pangan tersebut masih di bawah standar pola pangan harapan ( $\mathrm{PPH})$ yang telah ditetapkan yaitu sebesar 30,0. Selisih antara skor PPH aktual dengan standar PPH yang telah ditetapkan adalah sebesar 3 persen, hal ini menunjukkan bahwa konsumsi sayur dan buah di Kota Metro dapat digolongkan mendekati berimbang dan menarik untuk diteliti lebih lanjut. Tujuan penelitian ini adalah untuk mengetahui gaya hidup dalam mengonsumsi sayur dan buah, menganalisis tingkat kecukupan gizi, serta menganalisis faktor-faktor yang mempengaruhi konsumsi sayur dan buah anak usia sekolah dasar.

\section{METODE PENELITIAN}

Penelitian ini dilakukan dengan menggunakan metode survai. Metode survai adalah metode penelitian yang mengambil sampel dari satu populasi dan menggunakan kuesioner sebagai alat pengumpulan data yang pokok. Penelitian ini dilakukan di Kota Metro, yakni pada Sekolah Dasar Negeri 1 Kota Metro dan Sekolah Dasar Negeri 6 Kota Metro. Pengambilan sampel dilakukan menggunakan metode acak sederhana (simple random sampling). Sampel yang dibutuhkan dihitung berdasarkan teori Isaac dan Michael dalam Sugiarto (2003). Berdasarkan perhitungan dengan menggunakan rumus, diperoleh jumlah sampel sebanyak 52 anak. Proporsi sampel untuk SD Negeri 1 Kota Metro adalah sebanyak 36 anak dan pada SD Negeri 6 Kota Metro adalah sebanyak 16 anak didapatkan melalui metode acak proporsional. Responden penelitian ini adalah anak kelas lima SD yang sekolah di SD Negeri 1 Metro dan SD Negeri 6 Metro. Kedua sekolah tersebut dipilih secara sengaja untuk memudahkan penelitian dengan pertimbangan lokasi kedua sekolah berdekatan.

Data yang digunakan dalam penelitian ini adalah data primer dan data sekunder. Data primer diperoleh secara langsung dengan wawancara bersama responden dengan kuesioner yang berisi sejumlah pertanyaan yang berkaitan dengan gaya hidup dalam mengonsumsi sayur dan buah, pola konsumsi pangan, dan tingkat kecukupan gizi. Data sekunder diperoleh dari studi literatur dan lembaga atau instansi yang terkait dalam penelitian ini antara lain, BPS, DKP Provinsi Lampung, dan DKP Kota Metro seperti data perkembangan konsumsi penduduk Provinsi Lampung dan kualitas konsumsi pangan penduduk Kota Metro berdasarkan skor PPH. Untuk menjawab tujuan penelitian, digunakan analisis deskriptif kuantitatif dan verifikatif. Konsumsi dan tingkat kecukupan gizi anak usia sekolah dianalisis dengan menghitung jumlah asupan gizi anak menggunakan metode recall yaitu dengan menanyakan kembali semua jenis makanan yang dimakan individu atau kelompok dalam waktu 1x24 jam terakhir dalam satu hari, kemudian ditaksir beratnya dan dihitung kandungan gizinya menggunakan Tabel Komposisi Pangan Indonesia (2017). Rumus yang digunakan untuk mengetahui kandungan gizi bahan makanan Hardinsyah (1989) adalah:

$$
\mathrm{KG}=\left(\frac{\mathrm{B}}{100} \times \mathrm{G} \times \frac{\mathrm{BDD}}{100}\right)
$$

Keterangan:

$$
\begin{aligned}
\mathrm{KG}= & \text { Kandungan zat gizi (energi, protein, } \\
& \text { lemak, karbohidrat, kalsium, zat besi, } \\
& \text { dan vitamin A dan vitamin C yang } \\
& \text { dikonsumsi } \\
\mathrm{B}= & \text { Berat makanan (gram) } \\
\mathrm{G}= & \text { Kandungan zat gizi (energi, protein, } \\
& \begin{array}{l}
\text { lemak, karbohidrat, kalsium, zat besi, } \\
\text { dan vitamin A dan vitamin C) dalam }
\end{array} \\
& \text { tabel TKPI } \\
\mathrm{BDD}= & \text { Berat yang dapat dimakan }(100 \%)
\end{aligned}
$$

Angka Kecukupan Gizi (AKG) anak dapat dihitung berdasarkan berat badan anak menurut kelompok umur, jenis kelamin, dan aktivitas fisik dengan cara:

$\mathrm{AKG}=\frac{\text { BB Aktual }(\mathrm{kg})}{\text { BB Standar }(\mathrm{kg})} \mathrm{x}$ AKG standar.

Keterangan:

$\mathrm{AKG}=$ angka kecukupan gizi

$\mathrm{BB}=$ berat badan aktual

$\mathrm{AKG}$ standar $=\mathrm{AKG}$ dalam tabel angka kecukupan yang dianjurkan menurut WNPG IX (LIPI 2012)

Tingkat kecukupan gizi (TKG) atau persentase AKG dihitung dengan menggunakan rumus sebagai berikut (Indriani 2015):

$\mathrm{TKG}(\% \mathrm{AKG})=\frac{\mathrm{KG}}{\mathrm{AKG}}$.

Keterangan :

TKG : tingkat kecukupan zat gizi

KG : konsumsi zat gizi dalam satu hari

AKG : angka kecukupan zat gizi per hari 
Apabila konsumsi makanan seseorang telah dinilai TKGnya, maka dapat dinilai kualitas makanan secara keseluruhan dengan menghitung nilai ragam kecukupan gizi (NRKG) dengan menggunakan rumus berikut ini (Indriani 2015):

$$
\mathrm{NRKG}=\frac{\Sigma \% \text { AKG zat gizi dalam makanan }}{\sum \text { zat gizi yang dihitung di dalam makanan }}
$$

Kategori NRKG:

$$
\begin{array}{ll}
\text { Baik } & =\text { lebih dari } 80 \% \\
\text { Cukup } & =70-79 \% \\
\text { Sedang } & =60-69 \% \\
\text { Buruk } & =\text { kurang dari } 60 \%
\end{array}
$$

Untuk mengetahui gaya hidup dalam mengonsumsi sayur dan buah pada anak usia sekolah dasar diukur dengan aktivitas anak dalam mengonsumsi sayur dan buah, minat anak terhadap variasi konsumsi sayur dan buah, dan opini anak terhadap konsumsi sayur dan buah, ketiga indikator tersebut diukur dalam skala likert, dimana skor 1) sangat tidak sesuai, 2) kurang sesuai, 3) sesuai. Jawaban atas pertanyaan yang diajukan akan diukur dengan menggunakan Skala Likert. Skala Likert digunakan untuk mengukur persepsi seseorang terhadap suatu peristiwa dengan memberikan skor pada masing-masing variabel yang diteliti. Pada penelitian ini dilakukan uji validitas dan reliabilitas kuesioner untuk mengumpulkan data. Data yang diperoleh berupa skala ordinal. Skala ordinal pada tiap indikator diubah menjadi skala interval dengan menggunakan metode Method of Successive (MSI) agar datanya dapat digunakan untuk dianalisis menggunakan regresi linier berganda. Faktorfaktor yang mempengaruhi konsumsi sayur dan buah anak usia sekolah dasar dianalisis menggunakan analisis regresi berganda. Model persamaannya adalah:

$$
\begin{aligned}
Y= & a+b_{1} X_{1}+b_{2} X_{2}+b_{3} X_{3}+b_{4} X_{4}+b_{5} X_{5}+ \\
& b_{6} X_{6}++b_{7} X_{7}+b_{8} X_{8}+b_{9} X_{9}+d_{1} D_{1}+e \ldots . .(5)
\end{aligned}
$$

\section{Keterangan:}

$$
\begin{aligned}
\mathrm{Y} & =\text { Konsumsi sayur dan buah (kkal) } \\
\mathrm{A} & =\text { Bilangan konstan } \\
\mathrm{b}_{1}-\mathrm{b}_{9}= & \text { Koefisien regresi } \\
\mathrm{d}_{1} & =\text { Koefisien dummy } \\
\mathrm{X}_{1} & =\text { Jumlah anggota keluarga (orang) } \\
\mathrm{X}_{2} & =\text { Pendapatan/uang saku (Rp/minggu) } \\
\mathrm{X}_{3} & =\text { Jumlah jenis sayur yang dikonsumsi } \\
& \text { (per minggu) } \\
\mathrm{X}_{4}= & \text { Jumlah jenis buah yang dikonsumsi } \\
& \text { (per minggu) }
\end{aligned}
$$

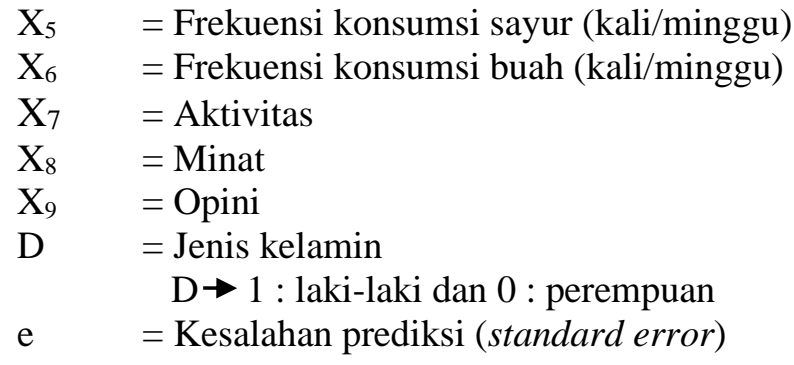

\section{HASIL DAN PEMBAHASAN}

\section{Karakteristik Responden}

Responden kedua sekolah pada penelitian ini yang lebih banyak jumlahnya adalah laki-laki yaitu sebanyak 27 orang $(51,92 \%)$. Masa anak-anak, aktivitas fisiknya meningkat sehingga kebutuhan gizi meningkat. Anak laki-laki lebih cepat menguasai kemampuan motorik seperti melompat, menyeimbangkan tubuh, serta berlari jika dibandingkan dengan anak perempuan (WHO 2003). Pada penelitian ini, responden berasal dari beragam suku bangsa yaitu suku Jawa, Lampung, Padang, Palembang, Sunda, dan Banten. Suku bangsa responden kedua sekolah yang tertinggi adalah suku Lampung (36,54\%).

Jumlah anggota keluarga dapat berpengaruh terhadap konsumsi sayur dan buah pada responden. Jumlah anggota keluarga responden berkisar antara empat sampai enam orang. Pendidikan ibu dinilai penting bagi kecukupan gizi responden karena ibu berperan sebagai penyedia pangan yang bergizi seimbang di rumah. Ibu responden berpendidikan terakhir SMA $(48,07 \%)$ dan S1 (30,77\%). Uang saku merupakan salah satu faktor yang berkaitan dengan gaya hidup dalam mengonsumsi sayur dan buah karena gaya hidup merupakan kegiatan seseorang dalam menggunakan uang dan waktunya (Suryani 2012). Sebagian besar uang saku responden dari kedua sekolah berkisar antara Rp1.000,- - Rp5.000,- yaitu sebesar 61,54 persen dari total responden.

\section{Konsumsi Sayur dan Buah}

Konsumsi sayur dan buah anak dilihat dari lima jenis sayur dan lima jenis buah yang paling banyak diminati oleh anak. Sayuran yang paling banyak diminati adalah kangkung, bayam, kacang panjang, terong ungu, dan wortel. Rata-rata konsumsi sayur pada anak adalah sebesar 91,39 gram/hari atau sebesar 26,03 kkal/hari dengan frekuensi makan rata-rata $2 \mathrm{kali} /$ hari. Buah-buahan yang paling banyak dikonsumsi adalah jeruk, pisang, pepaya, rambutan, dan jambu biji. Rata-rata konsumsi 
buah pada anak adalah sebesar 120,22 gram/minggu atau sebesar 55,86 kkal/hari dengan frekuensi makan rata-rata $2 \mathrm{kali} / \mathrm{hari}$. Menurut Almatsier (2001), porsi sayuran yang dianjurkan untuk dimakan sehari adalah sebanyak 150-200 gram dan porsi buah yang dianjurkan adalah sebanyak 200-300 gram. Hal ini menunjukkan bahwa konsumsi sayur dan buah anak masih dibawah standar yang dianjurkan. Kurangnya konsumsi sayur dan buah pada anak dapat mengakibatkan kurangnya asupan vitamin dan mineral pada tubuh anak, sehingga dapat mempengaruhi pertumbuhan dan perkembangan anak di masa yang akan datang.

\section{Gaya Hidup}

Gaya hidup menunjukkan pada bagaimana seseorang menggunakan pendapatannya, dan memilih produk ataupun pilihan yang ada dari berbagai alternatif pilihan yang disediakan (Suryani 2012). Pada penelitian ini, gaya hidup menunjukkan bagaimana anak menggunakan uang sakunya dan memilih produk sayur dan buah untuk dikonsumsi. Gaya hidup anak dalam mengonsumsi sayur dan buah pada penelitian ini dilihat dari aktivitas, minat, dan opini.

Gaya hidup anak dari segi aktivitas menunjukkan bahwa sebesar 61,54 persen anak usia Sekolah Dasar dalam penelitian ini rutin mengonsumsi sayur dan buah segar yang disediakan di rumahnya. Anak jarang membawa bekal sayuran ke sekolah $(42,31 \%)$. Anak jarang membeli sayur dan buah yang telah diolah menjadi jus, salad, asinan, rujak, petisan, dan sup buah karena sebagian besar anak lebih memilih mengonsumsi buah segar yang disediakan dan membuat sendiri olahan seperti jus buah di rumah. Hal ini sejalan dengan penelitian Andarwangi, Indriani, dan Prasmatiwi (2015), yaitu intensitas responden dalam membeli jus buah sangat jarang $(73,3 \%)$ karena responden akan membeli jus buah apabila sedang pergi bersama keluarga di restoran.

Hasil penelitian gaya hidup dalam segi minat menunjukkan bahwa sebagian besar anak lebih suka membeli sayur dan buah di pasar tradisional dibandingkan dengan pasar modern dan kios buah $(63,46 \%)$. Hal ini disebabkan harga di pasar tradisional cenderung lebih rendah dibandingkan dengan harga di pasar modern dan letak pasar tradisional dekat dengan sekolah. Anak lebih memilih buah lokal dibandingkan dengan buah impor $(61,54 \%)$ karena buah lokal lebih mudah didapatkan dan harga buah lokal lebih terjangkau jika dibandingkan dengan buah impor. Anak jarang membawa bekal sayuran ke sekolah $(42,31 \%)$ dikarenakan kesibukan orangtuanya sehingga tidak sempat untuk membekali anak dan anak lebih senang untuk membeli makanan yang disediakan di kantin sekolah. Hal ini sejalan dengan penelitian Andarwangi et al (2015) yaitu rumah tangga kurang menyukai membekali anak buah-buahan $(56,6 \%)$ karena kesibukan orang tua yang cukup padat.

Pada penelitian ini, opini menunjukkan pandangan atau penilaian anak terhadap konsumsi sayur dan buah. Hasil penelitian menunjukkan bahwa sebagian besar anak setuju dengan opini mengonsumsi sayur dan buah merupakan kegiatan yang penting dilakukan karena akan berdampak baik bagi kesehatan $(78,85 \%)$. Anak setuju bahwa mengonsumsi sayur dan buah secara rutin dapat mencegah penyakit kanker $(80,77 \%)$. Selain itu, anak setuju dengan pendapat bahwa mengonsumsi sayur dan buah secara rutin dapat mengurangi kolesterol karena banyaknya kandungan serat di dalamnya $(76,92 \%)$.

\section{Tingkat Kecukupan Gizi}

Perhitungan tingkat kecukupan gizi anak dihitung dari sembilan zat gizi yang dikonsumsi oleh anak. Penelitian ini menghitung tingkat kecukupan zat gizi energi, protein, lemak, karbohidrat ,kalsium, fosfor, zat besi, vitamin $\mathrm{A}$, dan vitamin $\mathrm{C}$ merujuk pada penelitian Andriani, Indriani, dan Adawiyah (2015). Zat gizi makro terdiri dari energi, lemak, protein dan karbohidrat. Zat gizi mikro terdiri dari kalsium, fosfor, besi, vitamin A, dan vitamin C. Zat gizi makro dan mikro dibutuhkan oleh anak untuk menunjang pertumbuhan, perkembangan, dan daya pikir anak.

Nilai Ragam Kecukupan Gizi (NRKG) dihitung untuk melihat kualitas konsumsi pangan pada anak. Pada penelitian ini, NRKG didapat dari menghitung sembilan macam zat gizi. Rata-rata hasil perhitungan $\mathrm{AKG}$, konsumsi, TKG, dan NRKG berdasarkan kandungan zat gizi dapat dilihat pada Tabel 1. 
Tabel 1. Rata-rata hasil perhitungan AKG, konsumsi, TKG, dan NRKG berdasarkan kandungan zat gizi

\begin{tabular}{lrrrrrrrrr}
\hline & \multicolumn{1}{c}{ Kandungan Zat Gizi } \\
\cline { 2 - 9 } & Energi & Protein & Lemak & Karbohidrat & Kalsium & Fosfor & Besi & Vit A & Vit C \\
\hline \multirow{2}{*}{ AKG } & $2.075,8 \mathrm{kkal}$ & $051,3 \mathrm{~g}$ & $70,6 \mathrm{~g}$ & $283,8 \mathrm{~g}$ & $1211,9 \mathrm{mg}$ & $1262,4 \mathrm{mg}$ & $13,5 \mathrm{mg}$ & $605,9 \mathrm{RE}$ & $50,4 \mathrm{mg}$ \\
Konsumsi & $1.999,8 \mathrm{kkal}$ & $53,3 \mathrm{~g}$ & $68,0 \mathrm{~g}$ & $264,3 \mathrm{~g}$ & $533,7 \mathrm{mg}$ & $739,9 \mathrm{mg}$ & $13,8 \mathrm{mg}$ & $500,1 \mathrm{RE}$ & $22,6 \mathrm{mg}$ \\
TKG (\%) & 101,7 & 108,3 & 100,2 & 100,0 & 47,2 & 61,7 & 108,2 & 84,6 & 48,4 \\
\hline NRKG & & & & $85 \%$ & & & & \\
\hline
\end{tabular}

Berdasarkan data pada Tabel 1, dapat diketahui bahwa rata-rata anak memiliki nilai ragam kecukupan baik (85\%). Hal ini menunjukkan bahwa pangan yang dikonsumsi anak usia Sekolah Dasar sudah beragam. Sebagian besar anak telah mengonsumsi makanan dengan jumlah yang cukup. Pada penelitian ini, terdapat lima kategori tingkat kecukupan gizi berdasarkan zat gizi makro, yaitu defisit berat (<70\%), defisit ringan (70-79\%), cukup (80-89\%), normal (90-109\%), dan kelebihan $(>110 \%)$. Sebaran tingkat kecukupan gizi anak usia Sekolah Dasar di Kota Metro menurut zat gizi makro dapat dilihat pada Tabel 2.

Berdasarkan data pada Tabel 2, kategori tingkat kecukupan gizi anak diringkas menjadi dua kategori yaitu cukup-kelebihan dan defisit ringandefisit berat untuk mempermudah pembaca. Zat gizi makro berupa energi menempati urutan tertinggi dalam kategori cukup-kelebihan $(69,4 \%)$. Sebesar 63,6 persen anak banyak mengonsumsi makanan berlemak yang mengakibatkan jumlah energi dalam tubuh kelebihan. Menurut Berg (1986), kebanyakan anak-anak lebih menyukai untuk mengkonsumsi makanan dengan kandungan lemak jenuh dan energi tinggi lebih dari yang direkomendasikan serta tinggi dalam mengkonsumsi makanan dan minuman dengan pemanis buatan, namun rendah dalam mengkonsumsi sayur dan buah. Pada kategori defisit ringan-defisit berat didominasi oleh anak yang mengalami kekurangan protein $(42,2 \%)$ dan karbohidrat $(38,4 \%)$. Peran protein sangat penting bagi tubuh karena berfungsi sebagai zat penyusun atau pembangun tubuh yang tidak bisa digantikan oleh zat gizi lainnya. Hal ini diduga karena sebagian besar anak usia Sekolah Dasar di Kota Metro kurang mengonsumsi pangan yang mengandung protein seperti ikan, telur, dan daging.

Pada Tabel 3, dapat diketahui bahwa sebagian besar anak mengalami defisit kalsium dan vitamin $\mathrm{C}$ yaitu masing-masing sebanyak 43 orang karena nilai \%AKG nya kurang dari 70 persen. Hal ini sejalan dengan penelitian Pertiwi, Hardinsyah, dan Ekawidyani (2014) yaitu sebagian besar anak memiliki tingkat kecukupan zat gizi mikro dalam kategori defisit yaitu defisit vitamin A, vitamin C, kalsium, dan fosfor. Penelitian Marliyanti, Nugrah, dan Anwar (2014) juga menunjukkan bahwa lebih dari separuh subjek $(58,1 \%)$ memiliki status vitamin A dengan kategori rendah. Tingkat kecukupan zat besi dan vitamin B pada sebagian besar anak masuk dalam kategori normal. Kekurangan kalsium, fosfor, vitamin A, dan vitamin $\mathrm{C}$ dapat mengganggu pertumbuhan tulang dan gigi. Pada masa anak-anak, kebutuhan fisiknya meningkat sehingga kebutuhan gizinya juga meningkat. Jika hal ini diabaikan, maka akan membahayakan pertumbuhan dan perkembangan anak di masa yang akan datang. Konsumsi sayur dan buah kurang juga dapat mempengaruhi pertumbuhannya, karena sayur dan buah kaya akan vitamin, mineral, dan serat yang dibutuhkan tubuh.

Tabel 2. Sebaran tingkat kecukupan gizi anak usia Sekolah Dasar di Kota Metro berdasarkan zat gizi makro

\begin{tabular}{lcccc}
\hline \multicolumn{1}{c}{ Kotegori Znt Gizi Molro } & \multicolumn{2}{c}{ Defisit Ringan-Defisit Berat } & \multicolumn{2}{c}{ Cukup -Kelebihan } \\
\hline & Jumlah & $\%$ & Jumlah & $\%$ \\
\hline Energi & 16 & 30,6 & 36 & 69,4 \\
Lemak & 19 & 36,4 & 33 & 63,6 \\
Protein & 22 & 42,2 & 30 & 57,7 \\
Karbohidrat & 20 & 38,4 & 32 & 61,6 \\
\hline
\end{tabular}


Tabel 3. Sebaran tingkat kecukupan gizi anak usia Sekolah Dasar di Kota Metro berdasarkan zat gizi mikro

\begin{tabular}{lccccc}
\hline \multirow{2}{*}{ Kategori Zat Gizi Mikro } & \multicolumn{3}{c}{ Defisit } & & \multicolumn{2}{c}{ Normal } \\
\cline { 2 - 3 } \cline { 5 - 6 } Kalsium & Jumlah & $\%$ & 82,69 & Jumlah & 17,31 \\
Fosfor & 43 & 71,15 & 9 & 15 & 28,85 \\
Besi & 37 & 26,92 & 38 & 73,08 \\
Vitamin A & 14 & 57,69 & 22 & 42,31 \\
Vitamin B & 30 & 25,00 & 39 & 75,00 \\
Vitamin C & 13 & 82,69 & 9 & 17,31 \\
\hline
\end{tabular}

Faktor -faktor yang Mempengaruhi Konsumsi Sayur dan Buah Anak

Analisis regresi berganda digunakan untuk menganalisis pengaruh satu variabel terikat dengan dua atau lebih variabel bebas. Faktor-faktor konsumsi sayur dan buah pada anak usia Sekolah Dasar yang digunakan menjadi variabel bebas dalam model adalah jumlah anggota keluarga $\left(\mathrm{X}_{1}\right)$, uang saku $\left(\mathrm{X}_{2}\right)$, jumlah jenis sayur yang dikonsumsi $\left(X_{3}\right)$, jumlah jenis buah yang dikonsumsi $\left(\mathrm{X}_{4}\right)$, frekuensi konsumsi sayur (kali/minggu) $\left(\mathrm{X}_{5}\right)$, frekuensi konsumsi buah (kali/minggu) $\left(\mathrm{X}_{6}\right)$, aktivitas $\left(\mathrm{X}_{7}\right)$, minat $\left(\mathrm{X}_{8}\right)$, opini $\left(\mathrm{X}_{9}\right)$, dan jenis kelamin (D). Hasil analisis regresi linier berganda terhadap konsumsi sayur dan buah anak usia Sekolah Dasar di Kota Metro disajikan pada Tabel 4. Model persamaan regresi yang dihasilkan yaitu sebagai berikut:

$$
\begin{aligned}
\mathrm{Y}= & 75,228-1,330 \mathrm{X}_{1}+0,000 \mathrm{X}_{2}+25,659 \mathrm{X}_{3}- \\
& 57,442 \mathrm{X}_{4}+15,195 \mathrm{X}_{5}+33,406 \mathrm{X}_{6}-11,173 \\
& \mathrm{X}_{7}-22,049 \mathrm{X}_{8}+49,922 \mathrm{X}_{9}+23,304 \mathrm{D}+\mathrm{e}
\end{aligned}
$$

Berdasarkan nilai signifikansi masing-masing variabel pada Tabel 4 diketahui bahwa variabel jumlah jenis sayur yang dikonsumsi $\left(\mathrm{X}_{3}\right)$, jumlah jenis buah yang dikonsumsi $\left(\mathrm{X}_{4}\right)$, frekuensi konsumsi sayur $\left(\mathrm{X}_{5}\right)$, frekuensi konsumsi buah $\left(\mathrm{X}_{6}\right)$, dan opini $\left(\mathrm{X}_{9}\right)$ berpengaruh nyata terhadap konsumsi sayur dan buah anak usia Sekolah Dasar. Variabel yang tidak berpengaruh nyata terhadap konsumsi sayur dan buah anak usia Sekolah Dasar adalah jumlah anggota keluarga $\left(\mathrm{X}_{1}\right)$, uang saku $\left(\mathrm{X}_{2}\right)$, aktivitas $\left(\mathrm{X}_{7}\right)$, minat $\left(\mathrm{X}_{8}\right)$, dan jenis kelamin (D). Hal ini sejalan dengan penelitian Mohammad dan Madanijah (2015) yang menyimpulkan bahwa besarnya anggota keluarga tidak menunjukkan hubungan yang signifikan dengan konsumsi sayur dan buah subjek dan uang saku subjek tidak berhubungan dengan konsumsi sayur dan buah karena sebagian besar siswa tidak mengalokasikan uang sakunya untuk membeli jajanan yang berbahan dasar sayuran. Namun, uang saku berpengaruh signifikan pada konsumsi buah anak usia Sekolah Dasar. Hasil penelitian ini sejalan dengan penelitian Anggraeni dan Sudiarti (2018) yang menunjukkan bahwa jenis kelamin tidak berpengaruh nyata terhadap konsumsi sayur dan buah. Tidak ada perbedaan konsumsi buah dan sayur antara responden laki-laki dan perempuan.

\begin{tabular}{|c|c|c|c|c|}
\hline Variabel & Koefisien & $\mathrm{t}$ & Sig. & VIF \\
\hline Konstanta & 75,228 & 0,851 & 0,400 & 1,134 \\
\hline Jumlah anggota keluarga $\left(\mathrm{X}_{1}\right)$ & $-1,330$ & $-0,168$ & 0,868 & 1,074 \\
\hline Uang saku $\left(\mathrm{X}_{2}\right)$ & 0,000 & $-0,630$ & 0,532 & 1,597 \\
\hline Jumlah jenis sayur yang dikonsumsi $\left(\mathrm{X}_{3}\right)$ & $25,659 * * *$ & 2,205 & 0,033 & 1,748 \\
\hline Jumlah jenis buah yang dikonsumsi $\left(\mathrm{X}_{4}\right)$ & $-57,442 * * *$ & $-4,195$ & 0,000 & 1,483 \\
\hline Frekuensi konsumsi sayur $\left(\mathrm{X}_{5}\right)$ & $15,195 * * *$ & 9,162 & 0,000 & 1,559 \\
\hline Frekuensi konsumsi buah $\left(\mathrm{X}_{6}\right)$ & $33,406 * * *$ & 28,994 & 0,000 & 1,863 \\
\hline Aktivitas $\left(\mathrm{X}_{7}\right)$ & $-11,173$ & $-0,959$ & 0,343 & 2,532 \\
\hline Minat $\left(\mathrm{X}_{8}\right)$ & $-22,049$ & $-1,630$ & 0,111 & 1,844 \\
\hline Opini $\left(\mathrm{X}_{9}\right)$ & $49,922 * * *$ & 4,131 & 0,000 & 1,186 \\
\hline Jenis kelamin (D) & 23,304 & 1,267 & 0,212 & 1,134 \\
\hline F Statistic & 187,17 & R squared & & 0,979 \\
\hline Prob F Statistic & 0,000 & Prob Chi Square & & 0,144 \\
\hline Adjusted R Squared & 0,973 & & & \\
\hline
\end{tabular}

Tabel 4. Hasil analisis regresi linier berganda terhadap konsumsi sayur dan buah pada anak usia sekolah dasar di Kota Metro 


\section{KESIMPULAN}

Anak usia Sekolah Dasar di Kota Metro jarang membeli sayur dan buah yang telah diolah menjadi jus, salad, asinan, rujak, petisan, dan sup buah karena sebagian besar anak lebih memilih mengonsumsi buah segar yang disediakan di rumah. Anak lebih berminat dengan buah lokal yang dibeli di pasar tradisional dibandingkan dengan buah impor karena buah lokal lebih mudah didapatkan dan harga buah lokal lebih terjangkau jika dibandingkan dengan buah impor. Sebagian besar anak setuju dengan opini mengonsumsi sayur dan buah merupakan kegiatan yang penting dilakukan karena dengan mengonsumsi sayur dan buah akan berdampak baik bagi kesehatan. Tingkat kecukupan gizi makro (energi, karbohidrat, lemak, dan protein) masuk dalam kategori kelebihan. Sebesar 82,69 persen anak usia Sekolah Dasar di Kota Metro mengalami defisit zat gizi mikro yaitu kalsium dan vitamin $C$. Berdasarkan Nilai Ragam Kecukupan Gizi, pangan yang dikonsumsi anak usia Sekolah Dasar sudah beragam. Faktor-faktor yang mempengaruhi konsumsi sayur dan buah pada anak usia Sekolah Dasar di Kota Metro adalah jumlah jenis sayur yang dikonsumsi, jumlah jenis buah yang dikonsumsi, frekuensi konsumsi sayur, frekuensi konsumsi buah dan opini anak.

\section{DAFTAR PUSTAKA}

Andarwangi $\mathrm{T}$, Indriani $\mathrm{Y}$, dan Prasmatiwi FE. 2016. Gaya hidup dalam mengonsumsi buahbuahan pada rumah tangga yang memiliki anak usia sekolah dasar di Bandar Lampung. JIIA, 4(1): 94-103. http://jurnal.fp.unila.ac.id/index.php/JIA/articl e/view/1219 [10 Desember 2017].

Andriani VL, Indriani Y, dan Adawiyah R. 2015. Pola makan dan kecukupan gizi balita pada keluarga petani jagung. JIIA, 3(4): 419-425. http://jurnal.fp.unila.ac.id/index.php/JIA/articl e/view/1092/997 [10 Desember 2017].

Almatsier S. 2001. Prinsip Dasar Ilmu Gizi. PT Gramedia Pustaka Utama. Jakarta.

Anggraeni NA dan Sudiarti T. 2018. Faktor dominan konsumsi buah dan sayur pada remaja di SMPN 98 Jakarta. Indonesian Journal of Human Nutrition, 5(1): 18-32. https://ijhn.ub.ac.id/index.php/ijhn/article/vie w/221 [29 Juli 2018].
Berg A. 1986. Peranan Gizi Dalam Pembangunan Nasional. CV Rajawali. Jakarta.

DKP [Dinas Ketahanan Pangan] Kota Metro. 2017. Laporan Akhir Kegiatan Analisis PPH Tahun 2016. DKP Kota Metro. Kota Metro

Hardinsyah. 1989. MenaksirKecukupan Energi dan Protein serta Penilaian Status Konsumsi Pangan. Wirasari. Jakarta.

Harper LJ, Deaton BJ, dan Driskel JA. 1986. Pangan, Gizi dan Pertanian. Penerjemah Suhardjo. UI Press. Jakarta.

Indriani Y. 2015. Gizi dan Pangan. Anugrah Utama Raharja. Bandar Lampung.

LIPI [Lembaga Ilmu Pengetahuan Indonesia]. 2012. Prosiding Widyakarya Nasional Pangan dan Gizi IX. LIPI. Jakarta.

Marliyanti SA, Nugraha A, dan Anwar F. 2014. Asupan vitamin A, status vitamin A, dan status gizi anak usia sekolah dasar di Kecamatan Leuwiliang, Kabupaten Bogor. Jurnal Gizi dan Pangan, 9(2): 109-116. http://journal.ipb.ac.id/index.php/jgizipangan/ article/view/8729/6810 [10 Desember 2017].

Mohammad A dan Madanijah S. 2015. Konsumsi buah dan sayur anak usia sekolah dasar di Bogor. Jurnal Gizi Pangan, 10 (1):71-76. http://journal.ipb.ac.id/index.php/jgizipan gan/article/view/9315 [10 Desember 2017].

Pertiwi KI, Hardinsyah, dan Ekawidyani KR. 2014. Konsumsi pangan dan gizi serta skor pola pangan harapan (PPH) pada anak usia sekolah 7-12 tahun di Indonesia. Jurnal Gizi dan Pangan, 9 (2): 117-124. http://journal.ipb.ac.id/index.php/jgizipangan/ article/viewFile/8730/6811 [10 Desember 2017].

Santoso S. 2011. Kesehatan dan Gizi. Rineka Cipta. Jakarta.

Sugiarto DS. 2003. Metode Statistika untuk Bisnis dan Ekonomi. PT Gramedia Pustaka. Jakarta.

Soewitomo S. 2007. Sajian dalam Wadah Praktis. PT Gramedia Pustaka Utama. Jakarta.

Suryani T. 2012. Perilaku Konsumen Implikasi dan Strategi Pemasaran Edisi Pertama, Cetakan Ke Dua. Graha Ilmu. Yogyakarta.

[WHO] World Health Organization. 2003. Fruit and Vegetable Intake a Sampe of 11-year-old Children in 9 Europian Countries: The Pro Children Cross-Sectional Survey. An Nutr Metab, 49:236-245. 